\title{
A Sorting Place
}

\section{Philip Schultz}

The sheet was translucent. A kind of fire. He said to himself, Morning. And it was, all over the sheet he lay beneath, head to toe. His bandaged wrists didn't hurt, which seemed wrong. He wanted them to hurt. The doctor's shadow was saying someone wanted to speak to him on the phone. He listened to the warm sound of the doctor's talk. It was like bath water. Inside the white blur of cotton he opened his eyes to slits. Light was heaviest over his chest. Like a strap. But he wasn't strapped down. No, it was only light. The doctor said all he had to do was come out and walk a few yards down the corridor to the phone. That was all. It would be good for him. It was a friend the doctor said. He shook his head no. He didn't want to come out, or couldn't. He heard the shadow sigh, then feet down the tile. Like hands clapping.

His body was very quiet. It didn't make a sound. He looked down at his toes and tried wiggling them. They wiggled. They wiggled fine. And his hands worked too. He lay opening and closing his eyes to the harsh light. He lay wiggling his toes and working his fingers on the sheets. Except for the slight spin behind his eyes, everything seemed in order. He wasn't even remembering anything. Only bits here and there, but nothing that amounted to anything; he was almost enjoying himself, his toes and fingers, his eyes. It was a joyful suspension; a kind he had known as a boy when floating face down in the lake for long moments without coming up for air. He recalled the green mist, the slow easy current of the lake's soft bottom; how he would float dreaming that he was in flight, high above any earthly disturbances. Floating between the sky and the earth, there were no possibilities of rejection. He was perfect then. Though now it seemed he floated at the bottom of the lake, looking up.

"Glass or razor, fella?"

The voice was a harsh whisper. Its shadow leaned across his chest like a smudge. He said, Huh?

"I asked ya glass or razor. Most use razors nowdays. We used to use broken mirrors. Times change."

For a moment it seemed something inside him spoke. But there was the shadow, swaying. He said, "Who are you?"

"Pop, just Pop. Been places like this off and on all my life almost. This yur first time, fella?"

He nodded, feeling the man's presence like a weight.

"Name?"

He tried to think of something simple. Couldn't.

"Scared, eh?" 
"Huh?"

"You're shakin, fella. We all do at first. Guess ya don't want out yet, eh? Just as well. Pretty crappy place this. They'll have beds hangin from the ceiling soon. But I've seen worse. What was it, a woman?"

He nodded, not knowing how to do nothing. Not because it was a woman, though for an instant he remembered that it was, but because suddenly nodding his head seemed the right thing to do. Like wiggling his toes. The light on the sheet grew warmer. He wondered how long it would be before it became hot. Was it summer? He couldn't recall. And he stopped nodding. He was angry that he couldn't recall the season.

"Usually is first time," Pop said. "Then ya learn more fancy reasons. Take Cosmo here ..."

A deep Negroid voice said, "Hiiii." A second shadow, twice as wide, moved over him. He whispered hello, cold beneath the shadows. It seemed a forest.

"Cosmo here likes to show his to folks," Pop said. "Mostly old ladies though. Aint that right, Cosmo?"

The big shadow nodded. "Guess so," it said.

"That a yawn, fella? Tired, eh? We're all tired at first. First time for me I slept three days straight. How about you, Cosmo?"

"Couple days is all."

"He says it was a woman, Cosmo. He cut his wrists, though he wont say glass or nothun. I saw them bring him in last night. Real weak, aint ya, fella?"

He wanted to regain that sense of floating. But it was gone. He wanted not to speak, but he didn't know how. The big shadow moved across his legs like a great bird. He was scared of it. More dead than alive, and he still could be scared of anything. Disgust filled his mouth with saliva. The world reeled above him beseeching him to speak, and he spoke. "Huh?" he said.

"I asked ya if ya felt real weak," Pop repeated.

He nodded, mumbled yes. He felt real weak.

"Hey, Cosmo, tell this young fella why ya show it to people all the time. Go on now, tell em!"

"Oh I dunno," Cosmo wavered, "I guess it's the only thing I got to show."

Pop laughed, slapping the bedpost. "Every time they let em out he goes an shows it to some old lady waitin for a bus an she screams so they come and bring em back here again. Never fails. This place is a kina sorting place where they put ya till they figure out where you go. Get me? Sometimes ya wait a while till they figure it out. I been places like this off and on all my life, almost."

"Been here four months this time," Cosmo said.

"But ya aint said whether it was glass or razor yet, and I want to know cause I'm kina keepin a record."

"Pop wants to know to see if ya tried a way he don't know yet. Every time they let em out he goes and tries a different way."

"That's right," Pop said. "But I aint found the right way yet. I guess I'm what they call a perfectionist. It got to be just right. But ya aint said yet, fella. Glass or razor?"

He tried to remember what he realized he didn't want to remember. But he 
tried, and his eyes burned. The light over the sheet was too bright suddenly. He believed he was sweating all over. He felt himself shrink with the loss. He shut his eyes and said, "Razor," because it sounded right. kind?"

"Oh yeah?" Pop said, then after a moment, added, "Gillette or some fancy

He rolled over on his stomach and buried his head under the pillow. Even under his shut eyes the light burned. Perhaps the doctor would come, but then he didn't really believe in rescue. He remembered that he had been rescued the night before. In the motel room. On the tile of the bathroom floor. He remembered a pale blue tile with red wings running over it. Perhaps the wings were his. He had been suspended then too. Face down on the floor yet hanging weightless somewhere between floor and ceiling. There was a fly, a dark brown fly, near the fluorescent light. He remembered it. Buzzing.

"Dont get sore, fella," Pop said as he sat on the bed. "It's just we aint got much to do here except ask new guys what they done. That's all. I dont mean no offense."

"Pop's alright," Cosmo said as he sat down next to Pop. The bed sagged on their side, and he had to hang onto the bedpost to keep from sliding toward them. The hard springs drew circles in his chest, and he could hear tiny moans deep within the coils of the mattress. He wished he could crawl into the privacy of the springs. And for the first time, his wrists hurt. a Semite?"

"He just likes talkin. Talkin and killin himself," Cosmo continued. "Say, you

He turned over on his side and tucked his wrists into his armpits. He felt protective, maternal. They were good wrists. It wasn't their fault they didn't bleed fast enough. He should have tried his throat.

"I asked if you was a Semite, fella" Cosmo yelled.

He sucked air into his lungs, then sighed. "What makes you ask?" Pop?"

"The way you talk, say words. Sound like a New York Semite to me. Dont he

"Something of the kind," Pop said. "But he could be a dago just as easy."

He thought about it: was he a Semite? He didn't want to think about anything. It angered him. He said, without thinking first, "Are you a Negro?"

"Huh?"

"He asked ya if you're black, Cosmo," Pop said.

Cosmo stood. The bed rocked. The big shadow moved over the sheet. Hung there. "Am I black?" Cosmo asked in a constricted voice. "What ya mean am I black?"

"He's only kiddin ya, Cosmo, aint ya fella?" Pop said, poking him in the thigh. "Aint ya, fella?" He poked again, harder.

"I'm kidding, Mr. Cosmo, I'm kidding," he said.

"Oh, well." Cosmo sat down on the bed again. The moans ran up and down the bed's spine. "Well," he began laughing. "Well, that aint so bad, hey. That's good. Only a Semite would think to ask that." He slapped the bed, twice.

"I think he is," Pop said. "But he could be a dago too. You never know for sure nowadays." 
"Naw, look at the shape of that nose. And ya said he did it over a chick. Who else kills emself over a chick?"

"I did once," Pop said.

"Awww, she-it, that was a hundred years ago. It dont count. I'm talkin about right now."

Their words buzzed his ears like flies. He felt he was listening from a great distance away, yet was part of everything that was said. For a few moments no one spoke. He curled into a ball and gritted his teeth. Perhaps they would leave if he pretended sleep. He pretended sleep.

Pop shook his shoulder, saying, "You sleepin, fella?"

"Leave em alone," Cosmo whispered.

"But I dont think he wants to be left alone, Cosmo. He may think he does, but he dont. None of us do."

"But he's sleepin, can't you see! These Semites need their sleep."

"Naw, he's only pretendin. How could he be sleepin when we're sittin here talkin so loud?"

"That's right," Cosmo said.

"That's right!" he said sitting up to his elbows, the sheet still over his head. "How can I be sleeping when you're both talking so loud?"

"Who was that called ya a while back?" Pop asked.

"I don't know," he said. "I didn't speak to them."

"Them? You mean yur folks?" silent.

He shrugged, stretching out as he imagined a corpse stretches out. Flat and

"Dont care for yur folks, eh?" Cosmo said. "Mine haven't called in years. Used to bring candy and gum every Sunday night, but no more. Remember, Pop? Bags full of apples and Life magazines. But no more. Not since they found out I was psycho-sexual. Now they dont want no part a me." $\mathrm{He}$ waited a moment, then said, "Ya ever know any?"

"Any what?"

"Psycho-sexuals. There's a lot round now I hear."

"Sure is," Pop laughed. "On every damn corner. It's safer in here."

"That's howcome I show it. It comes over me and I have to show it to someone. It aint like I go out lookin to show it. I aint no pervert."

The light grew darker across his face. Was it night already? His wrists itched. And the small of his back itched. Was the bed lousy? He tried to imagine who had slept there before him. Another attempted-suicide? A rapist, or a psycho-sexual like Cosmo? The old man Pop had said this was a sorting place. How would he be sorted out? Where would they put him? He told himself he didn't care. What did it matter? But he cared. His wrists hurt, his back ached. He could use a glass of water. Was it night? Then he remembered that it was late spring and that it would be summer soon.

"What's her name?" Pop asked. "This girl you did it for."

"Pooh," he heard himself say. "I did it for Pooh."

"Oh yeah? That's an interestin name."

He couldn't help it. He began shaking. First his hands then his whole body. 
He tried to hold it in so they wouldn't see. He bit his lips, but a noise still came out. A wheezing. He was remembering now.

"That's alright, man," Cosmo said. "Let it out, it'll clean ya out like an exlax. Nothun better, except maybe a good screw."

"Dont worry about us," Pop said, rubbing his hands on his knees. "We heard a guy cry before. Once we had to stuff a fella's throat with sheets to make his stop. All day all night he cried. Drove us nuts."

He stopped shaking. He imagined having sheets shoved down his throat. Pop slapped his foot.

"Want some water, fella?"

He shook his head no. Then he began choking.

"There's always worse," Pop said. "Listen, you got to learn to roll with the punch. This place aint Miami but I've seen worse."

"There's always worse," Cosmo said. "Once they put us in a place where we had to sleep standin up. Nothun's worse than that."

"Roll with the punch, swim with the tide," Pop continued.

"This chick," Cosmo asked, "was she a good screw?"

He stuffed his mouth with his fist. He couldn't believe the words. The question rang in his ears, his toes. The bed shook, or he shook it, he wasn't sure. And it was definitely getting darker. Roll with the punch. He was choking on his hand. He gasped for breath.

"That aint right to ask after a man just killed himself over the girl, Cosmo!"

"Didn't mean nothun by it."

"Listen, fella," Pop said. "It gets better. They dont keep ya here forever. Not the first time at least. Look, I got this scar that goes from my eye down to my chin, see?"

All he saw was the shadow.

"Know how I got it, fella?"

He shook his head.

"I put a shotgun under my chin. My old woman left me for a lousy dago years back. So I put it under my chin and shut my eyes and yelled, Here I come Fatso-open them fuckin gates!"

They were playing him for a fool. A shotgun would've blown his head off. There was a silence; they were waiting for him to ask the question. They would wait all night if they had to. He asked it, saying, "Okay, what happened?"

There was a great explosion of laughter. He heard voices from down the corridor, from under the bed; the room was filled with derisive laughter. The world had no mercy. He wished he were dead.

"What happened?" Pop cried, "why I blew my damn head off of course." He slapped the bed while Cosmo stood then sat down again, then stood, laughing. He knew they had been through the whole bit a hundred times but it still broke them up. He imagined every man in the room leaning over his bed anticipating the punchline for hours; they had heard every word. It was impersonal, he knew that, yet it hurt. It had nothing to do with him, yet he raged inside. Cosmo was still rising and falling on the bed, his booming voice bouncing wall to wall. 
Suddenly he was shouting at the top of his voice: "Why didn't you put it in your mouth, stupid?"

The voices stopped ringing. He felt Pop arrange himself on the bed. He felt the faces leaning forward, the ears straining. Pop adjusted his hands and in a soft thoughtful voice, said, drawing each word out, "Well, I never thought a that. Live an learn!"

It was night. He was still beneath the sheets. His face felt like a hot coal. He sat up, the sheets slipped from his face. Rows of beds ran along the wall down the long shadow-sliced corridor on either side of him. Like boats moored to the darkness, the beds seemed to float in the hollow air. And from what seemed very far away, a man's voice, muffled by sleep, called out what sounded like a woman's name. The sound persisted, hanging in the dark above his bed like a cornered echo; then, not many beds away, a man cursed in his sleep.

He felt his face, the eyes, the lips, the Semitic nose; it was all there. He felt cheated. At least a scar from eye to chin to show for it. His bowels burned. He had to piss. He functioned; he could see, he could feel and taste, and now piss. He looked up and down the corridor, over the sleeping forms stretched lifeless in dark rows; a sorting place, he remembered. It would all come back soon. It would all be over him like a wave. He climbed over the raised side of the bed and lowered himself into the dark water of the aisle. An arm's length away another man slept curled beneath a rough wool blanket, his dark blue foot sticking out over the side of the metal-frame bed. Light from the barred window across the aisle sliced the foot. It seemed carved from wax, unreal. The toilet would be to the right, he guessed, seeing that the corridor ended in shadow to the left. His feet slid over cold tile. He was very weak, and held onto the metal-frame, swaying. All his blood was gone. He held his pale wrist up to the moonlight; it seemed transparent. Inside his chest an emptiness coiled and uncoiled like a snake.

Across the aisle of beds, the moon hung like a lemon in the bleached dark of the window. He went from bed to bed toward it, feeling his head spin, and his heart shoot stabbing pains across his chest. He wanted to look outside, to see a street, any street. He held onto the bars, raising himself up to his toes in order to see out into the street below. The man to his left snored loudly, and cursed again.

Below, a small courtyard ran from the building to the high stone fence near the street; under the yellow glare of a streetlamp, it seemed a stage-setting, its small stone bench and heavily shadowed shrubs looked like papier-maché. Behind him men turned inside dreams, and one man down the aisle reached out a pale hand and moaned. The light caught the hand and froze it still for a moment. Then it fell back into the dark of the man's sleep. What was he doing in this place? This public pain. He knew no man in the room was really asleep. Outside, the moon hung pocked and discolored by the languid clouds. The white bandages glistened, 
and he could taste the darkness that weighed down on his face. Roll with the punch, swim with the tide. . . He put his face against the cold metal of the bars and relaxed the muscles in his body. What would they do with him? He pissed like an infant, warm and free, down his leg, swimming with the tide.

\section{Nuestra Senora, Reina de Los Angeles}

\section{Peter Israel}

She climbed from the white Mercedes. Through the window he watched her body bunch, then straighten before she launched up his path. If portraits were his line, he thought, he might paint one like that: big Venus on the half shell at middle age, bigger than Botticelli's. He'd blow her hair loose with a four-sided wind and strip the tweeds, let the shell crack.

He stopped working. The front door opened without a knock. He caught a brief glimpse of himself in blue coveralls, then she sailed into his studio like a judge at a county horseshow.

"Please leave me alone," she said after a few amenities. "I don't look at art in the presence of the artist."

By the kitchen sink he asked the pitcher: Don't or won't?, but the pitcher lacked ears. It stared back at him dumbly through eyes he'd added to either side of its beak. He might knock, and ask her. Please leave me alone, she said to him curtly, I'm looking at horses. He filled the pitcher to the brim and stepped past the sliding door of the living room into the dirt backyard with the view of the Santa Monica Mountains and the car graveyard. Every artist ought to experience Los Angeles, he'd decided, the brown haze rising off the brown hills like bad breath, the creep of detritus over the landscape. . . .

He couldn't remember when he'd watered the plants last. Cactus no more than once a week, someone had told him, too much water killed the cactus. Nothing else did. 